\title{
慢性腎不全患者の整形外科手術について
}

\author{
熊本中央病院 整形外科 \\ 森田直・前川 清 継 \\ 大 串幹 \\ 熊本大学病院 整形外科 \\ 岡 嶋 啓一郎 \\ 江南病院 整形外科 \\ 内賀島 英 明
}

\section{Clinical study of Orthopaedic Surgical Treatments in Chronic Renal Failure Patients.}

by

Sunao Morita, Kiyotsugu Maekawa, Miki Ogushi, Department of Orthopaedic Surgery, Kumamoto Chuo Hospital.

Keiichiro Okajima,

Department of Orthopaedic Surgery, Kumamoto Uiversity Medical School.

Hideaki Uchiga shima,

Department of Orthopaedic Surgery, Konan Hospital.

We treated operatively 13 hemodialysis patients for the orthopaedic diseases. One of them died of acut heart failure. The bony union in hemodialysis patients was almost same as non-hemodialysis patients in the term. The bleeding quantity for the femoral head replacement and osteosynthesis in hemodialysis patients was almost same but that for TKR and HTO in hemodialysis patients was almost twice as much as in non-hemodialysis patients. The rehabilitation in hemodialysis patients required longer term as compared with non-hemodialysis ones for their hemodialysis, complications, and original diseases.

\section{はじめに}

最近，透析技術の進歩により，透析患者の生存成績 が向上するにつれ高齿の患者が増加し，整形外科領域 における合併症を伴う事が多くなり，治療に手術を要 する機会が増えてきた。

我々は，術前，術中，術後の適正な管理を行えば, 透析患者にも一般整形外科手術は可能と考え, 積極的 に手術を施行してきた．今回，これらの症例の術後成 績をまとめるとともに, 若干の考察を加えて報告する.

対象及び方法

1983年 4 月より1987年 8 月までに入院加療した症例
は，12症例であった. 手根管症候群は外来局麻で行っ たので，これには含まれていない，対象症例は，大腿 骨頸部外側骨折 4 例，大腿骨頸部内側骨折 2 例，変 形性膝関節症 3 例，痛風性膝関節炎 1 例，化膿性 膝関節炎 1 例, 膝関節血腫 1 例，脛骨骨髄炎後の 皮虞㾇孔 1 例であった（表 1 ）.

手術方法は，骨接合術 4 例（エンダー釘 1 例, compression hip screw 3 例), 人工骨頭置換術 2 例（骨 セメント使用，ベイトマン，オムニフィット各 1 例)， 関節鏡 3 例, 持続洗浄 1 例, HTO 1 例（横浜市大式プ レート)，TKR 1 例（Ｉ／B II 型），植皮術 1 例の計13 例であった（表 2 ).

手術は全例腰椎麻酔下で行われ，一般患者と変わり 
なく行い，透析は術翌日より行った。

症例 1 ；69歳 女性 右大腿骨頸部外側骨折. 患者 は，RAによるアミロイドーシスを基礎疾患として 4 年の透析療法を受けていたが，転倒により受傷し当科 へ転院となった. Compression hip screw（以下 CHS) にて内固定を行い, 術後 7 日目より起立訓練を 開始した. 術中出血は180gであった. 透析日は全身倦 急のために術後の機能訓練が不可能で, 機能回復が一 般患者に比較し遅れた。術後約 2 力月で, 杖歩行にて 他の透析病院へ転院した. 現在, RA による両膝痛の ため歩行困難となっており, TKR を検討中である(図 1 ).

症例 $2 ; 69$ 歳 男性 右大腿骨頸部内側骨折, 患者 は，腎硬化症のために 3 年の透析療法を受けていたが, 陳旧性の内側骨折の診断で当科へ紹介入院となった。 オムニフィットの人工骨頭置換術をセメントを用いて

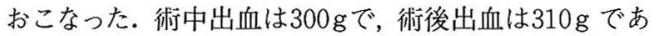
った. 術後 5 日目に, 胃潰瘍の出血のためにベッド上 安静となり, 術後12日目より起立訓練を開始した。術

表 1 透析患者の整形外科疾患

\begin{tabular}{ll}
\hline 大腿骨頸部外側骨折 & 4 例 \\
大腿骨頸部内側骨折 & 2 例 \\
変形膝関節症 & 3 例 \\
痛風性膝関節炎 & 1 例 \\
化膿性滕関節炎 & 1 例 \\
滕関節血腫 & 1 例 \\
脛骨骨鲔炎後の皮膚瘦孔 & 1 例 \\
\hline \multicolumn{1}{c}{ 計 } & 13 例
\end{tabular}

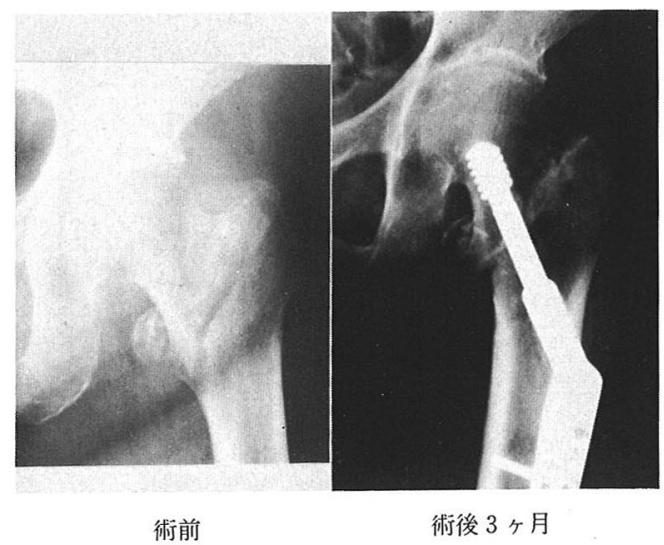

図 1 症例 $169 \mathrm{~F}$ 右大腿骨頸部外側骨折

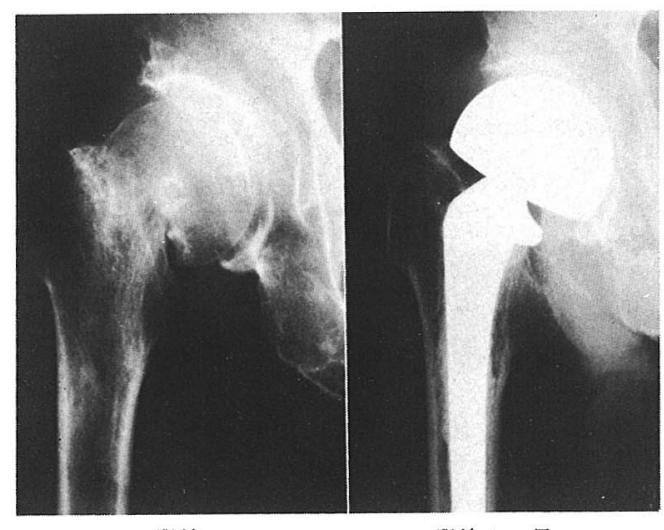

術前

術後 6 ヶ月

図 2 症例 $269 \mathrm{M}$ 右大腿骨頸部内側骨折

表 2 透析患者の整形外科手術例

\begin{tabular}{|c|c|c|c|c|}
\hline 症 例 & 診 & 原疾患(透析期間) & 術 & 予後 \\
\hline 1. $69 \mathrm{~F}$ & 大腿骨頝部外側骨折 & ( 4 年) & 骨接合術 & 生 \\
\hline 2. $44 \mathrm{M}$ & " & 腎 炎 ( 8 年) & 骨接合術 & 生 \\
\hline $3.69 \mathrm{~F}$ & " & DM （ 5 年) & 骨接合術 & 生 \\
\hline 4. $72 \mathrm{~F}$ & " & 腎 結 核 ( 1 年) & 骨接合術 & 生 \\
\hline 5. $69 \mathrm{M}$ & 大腿骨澒部内側骨折 & 腎硬化症（3 年） & 人工骨頭置換術 & 生 \\
\hline $6.71 \mathrm{~F}$ & " & DM （2 年) & 人工骨頭置換術 & 生 \\
\hline 7. $67 \mathrm{M}$ & 変形性膝関節症 & 炎（1 年) & $\mathrm{H} \quad \mathrm{T} \quad \mathrm{O}$ & 生 \\
\hline 8. $67 \mathrm{M}$ & " & 炎 (1 年) & $\begin{array}{lll}\mathrm{T} & \mathrm{K} & \mathrm{R}\end{array}$ & 生 \\
\hline $9.81 \mathrm{~F}$ & $"$ & 炎（1 年) & 関 節 鏡 & 生 \\
\hline 10. $55 \mathrm{M}$ & 痛風性滕関節炎 & ( 2 年) & 関 節 鏡 & 生 \\
\hline 11. $71 \mathrm{~F}$ & 化膿性膝関節炎 & （1 年) & 持続洗浄 & 死 \\
\hline 12. $77 \mathrm{M}$ & 溙 関 節 血 腫 & 炎（10年） & 関 節 鏡 & 生 \\
\hline 13. $64 \mathrm{M}$ & 怪骨骨骵炎後の皮䖉瘦孔 & ( 2 年) & 植 皮術 & 生 \\
\hline
\end{tabular}




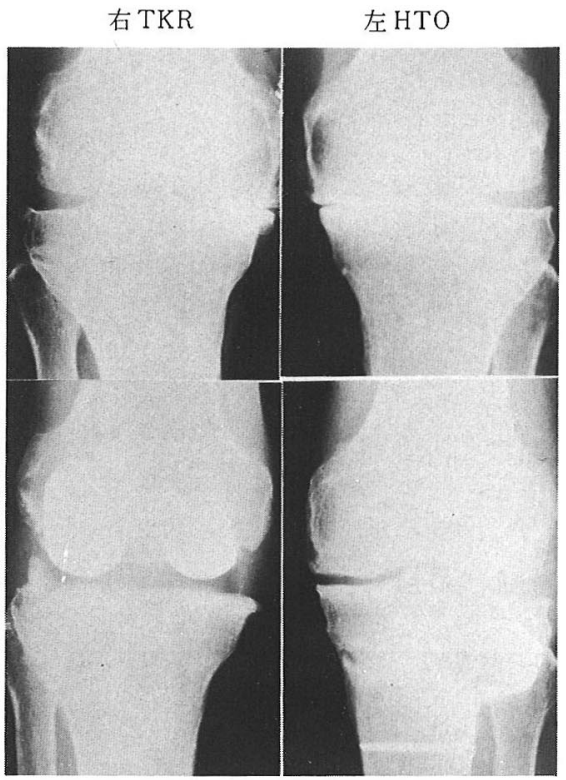

图 3 症例 $367 \mathrm{M}$ 両変形性膝関節症

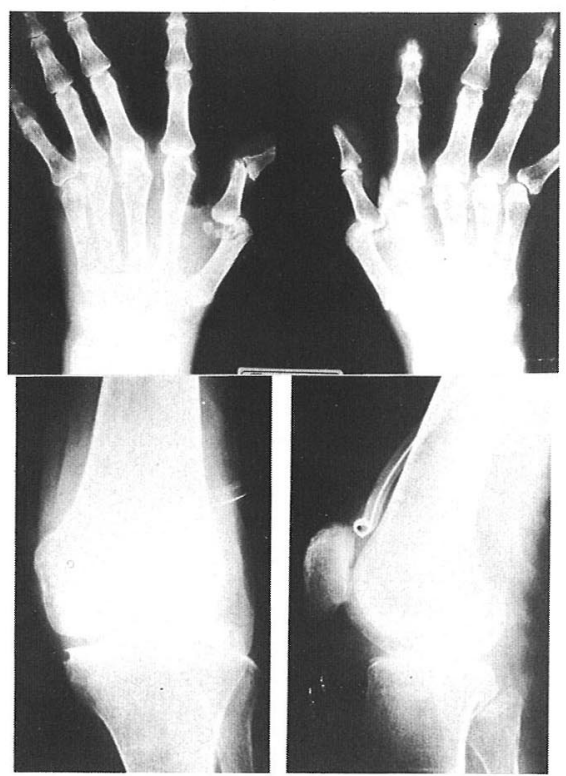

図 4 症例 $4 \quad 71 \mathrm{~F}$ 左化膿性䐂関節炎

表 3 透析患者の整形外科手術における問題点
1 . 骨癒合
2. 術中・術後の出血
3. 後療法の困難性

後 1 力月半にて杖歩行可能となり転院となった（図 2 ) 症例 $3 ; 67$ 歳 男性 両変形性膝関節症患者は, 腎 不全のため 1 年の透析療法を受けていたが, 両膝痛の ため歩行困難となり入院した。先ず，左膝にHTOを 横浜市大式プレートを用いて行った。 術中出血は, 駆 血帯不良のため $530 \mathrm{~g}$ で, 術後出血は522gであった。術 後 1 力月より部分荷重を開始したが, 骨切部が不安定 となったために術後 3 力月目より約 1 力月半キャスト 固定とした。次に，右溙に TKR を I/B I 型を用いて 行い, 術中出血 $600 \mathrm{~g}$, 術後出血 $1080 \mathrm{~g}$ であった. 1 回 目の手術より 7 力月後に, 松葉杖歩行にて転院となっ た（図 3 )。

症例 $4 ; 71$ 歳 女性 左化膿性膝関節炎患者は, RA によるアミロイドーシスを基礎疾患として，1年の透 析療法を受けていた. 当科入院時, CRP $6(+), W B C$ 12200 であり，関節鏡視下に滑膜切除後，持続洗浄を開 始した。起炎菌は，黄色ブドウ球菌であった。洗浄開 始後, 2 週間で洗浄液培養陰性化し CRP $( \pm), W B C$ 6100 となったので, 洗浄を中止した. その後, 内科へ 転科後, 心不全急性増悪のため死亡した。病理解剖で は，腹腔内に膿瘍が認められた（図 4 ）。

\section{結果及び考察}

透析患者の手術に際して，整形外科的に問題となる のは, 骨癒合, 術中・術後の出血, 後療法の困難性が あると思われる（表 3 )。

我々の症例の場合, 大腿骨頸部外側骨折に対し CHS を用いて骨隐合を待たずに荷重歩行させたが，著明な 骨折部の骨吸収像を示さずに，非透析例とほぼ同程度 の時期に骨癒合を示した，又，HTOで，骨切部に不 安定性がみられたが，これは，術後初期荷重が大きす ぎたために生じたものと思われる。

次に, 術中・術後の出血量を非透析例と比較する。 CHS の場合, 術中出血は透析例で平均 $99 \mathrm{~g}$, 非透析例 で平均 $163 \mathrm{~g}$ と，非透析例の方が出血量が多かった（表 4 ).

人工骨頭置換術では，術中出血は，透析例で平均 $200 \mathrm{~g}$, 非透析例で平均 $303 \mathrm{~g}$, 術後出血は, 透析例で平 均 $205 \mathrm{~g}$, 非透析例で平均 $188 \mathrm{~g}$ であった。合計すると, 透析例では平均 $405 \mathrm{~g}$, 非透析例では, 平均 $491 \mathrm{~g}$ であつ た（表 5 ).

TKR（I/B II 型）では, 術中出血は透析例で600 g, 
表 4 骨接合術（Compression hip screw）における 出血量の比較

\begin{tabular}{c|c}
\hline & 術 中 出 血 量 \\
\hline $\begin{array}{c}\text { 透 析 ( } 3 \text { 例) } \\
\text { (平均70才) }\end{array}$ & $\begin{array}{c}47 \mathrm{~g} \sim 180 \mathrm{~g} \\
\text { (平均99 } \mathrm{g} \text { ) }\end{array}$ \\
\hline $\begin{array}{c}\text { 非透析 (20例) } \\
\text { (平均77才) }\end{array}$ & $\begin{array}{c}30 \mathrm{~g} \sim 350 \mathrm{~g} \\
\text { (平均 } 163 \mathrm{~g})\end{array}$ \\
\hline
\end{tabular}

表 5 人工骨置換術における出血量の比較

\begin{tabular}{c|c|c}
\hline & 術中出血量 & 術後出血量 \\
\hline $\begin{array}{c}\text { 透 析 ( } 2 \text { 例) } \\
\text { (平均70才) }\end{array}$ & $\begin{array}{c}100 \mathrm{~g} \sim 300 \mathrm{~g} \\
\text { (平均200 } \mathrm{g})\end{array}$ & $\begin{array}{c}100 \mathrm{~g} \sim 310 \mathrm{~g} \\
\text { (平均205 } \mathrm{g} \text { ) }\end{array}$ \\
\hline $\begin{array}{c}\text { 非透析 (13例) } \\
\text { (平均75 f) }\end{array}$ & $\begin{array}{c}150 \mathrm{~g} \sim 450 \mathrm{~g} \\
\text { (平均303 } \mathrm{g})\end{array}$ & $\begin{array}{c}80 \mathrm{~g} \sim 350 \mathrm{~g} \\
\text { (平均 } 188 \mathrm{~g})\end{array}$ \\
\hline
\end{tabular}

表 6 TKR (I/B II Type) における出血量の比較

\begin{tabular}{c|c|c}
\hline & 術中出血量 & 術後出血量 \\
\hline 透 析 (1 例) & $600 \mathrm{~g}$ & $1,040 \mathrm{~g}$ \\
\hline 非透析 (4 例) & $\begin{array}{c}150 \mathrm{~g} \sim 570 \mathrm{~g} \\
\text { (平均370 } \mathrm{g} \text { ) }\end{array}$ & $\begin{array}{c}219 \mathrm{~g} \sim 545 \mathrm{~g} \\
\text { (平均358 } \mathrm{g} \text { ) }\end{array}$ \\
\hline
\end{tabular}

表 7 HTO（横浜市大式プレート）における出血量の 比較

\begin{tabular}{c|c|c}
\hline & 術中出血量 & 術後出血量 \\
\hline 透 析 (1 例) & $530 \mathrm{~g}$ & $522 \mathrm{~g}$ \\
\hline 非透析 (10例) & $\begin{array}{c}100 \mathrm{~g} \sim 220 \mathrm{~g} \\
\text { (平均130 } \mathrm{g} \text { ) }\end{array}$ & $\begin{array}{c}260 \mathrm{~g} \sim 522 \mathrm{~g} \\
\text { (平均361 } \mathrm{g} \text { ) }\end{array}$ \\
\hline
\end{tabular}

非透析例で平均 $370 \mathrm{~g}$, 術後出血は, 透析例で $1040 \mathrm{~g}$, 非透析例で平均 $358 \mathrm{~g}$ であり, 透析例では術後出血が 非透析例に比し約2.9倍多くみられた（表 6 ).

HTO では, 術中出血は, 透析例で $530 \mathrm{~g}$, 非透析例 で平均 $130 \mathrm{~g}$, 術後出血は, 透析例で $522 \mathrm{~g}$, 非透析例で 平均 $361 \mathrm{~g}$ であり, 透析例では術後出血が非透析例に 比し約1.4倍多くみられた（表 7 ).

以上より，透析患者での骨接合術，人工骨頭置換術 における出血量は，非透析患者と同量か，逆に少ない 場合がある，TKR，HTOにおける場合，我々の症例 では，非透析例に比し約 2 倍以上の出血量がみられた が, 症例が少ないので明確ではないが, 骨切除面の多 い手術では，より多くの出血があるように思われた。
透析患者の場合，後療法の困難性がある．透析患者 は，透析による全身倦急のため透析日は訓練不能の状 態となる．また，種々の基礎疾患，合併症のために， 機能訓練が遅れ，非透析例に比し，より長期の訓練期 間を要した。

\section{ま と め}

1. 透析患者 13 症例に整形外科手術を施行し 1 例が不 幸な転帰をとった。

2. 透析患者の骨癒合は，非透析患者とほぼ同じ期間 で生じた。

3. 透析患者の人工骨頭置換術，骨接合術での出血量 は，対照群に比しほぼ同量であり，TKR，HTOで の出血量は, 対照群に比し約 2 倍の出血量を示した

4. 透析患者の後療法は，透析，合併症，基礎疾患の ために，対照群に比しより長期間要した。

\section{参 考 文 献}

1）中野善薰ほか：慢性腎不全患者の手術と管理。腎と 透析, $12: 697-700,1982$.

\section{質 問長崎大学 池田 定倫}

透析患者における術後感染の予防としての抗生剤の 使用量の何か規準があれば教えて下さい.

\section{解 答熊本中央病院 森田 直 \\ 一般患者の $1 / 2$ 量の抗生剤を予防投与しています.}

\section{発 言社保中京病院 鈴木 潔}

・抗生剤投与に関して

一般に透析患者における抗生剤血中半減期は24 36 時間とかなり延長しており，過量となり下痢，出血傾 向を沶こしやすい。したがって予防投与としては，そ の薬剤の特性を十分理解して慎重に投与すべきである.

質 問琉球大学 乗松 尋道

人工骨頭置換をした場合に loosening を早くおこし て問題になった事はありませんか.

\section{解 答熊本中央病院 森田 直} 症例が少いので明確ではないですが，現在のところ looseningは認めていません. 